\title{
Karyotypic differentiation through chromosome fusion and number reduction in Imparfinis hollandi (Ostariophysi, Heptapteridae)
}

\author{
Vladimir Pavan Margarido ${ }^{1}$ and Orlando Moreira-Filho ${ }^{2}$ \\ ${ }^{1}$ Centro de Ciências Biológicas e da Saúde, Universidade Estadual do Oeste do Paraná, Cascavel, \\ PR, Brazil. \\ ${ }^{2}$ Departamento de Genética e Evolução, Universidade Federal de São Carlos, São Carlos, SP, Brazil.
}

\begin{abstract}
The Neotropical Heptapteridae fish Imparfinis hollandi, endemic to the Iguaçu River Basin (Brazil), was cytogenetically analyzed and the diploid chromosome number of $2 n=42$ chromosomes was determined $(22 \mathrm{~m}+10 \mathrm{sm}+$ 10st), the lowest diploid number in this genus and family. Like other Heptapteridae species, only one NOR-bearing chromosome pair was detected by silver nitrate staining. Dark heterochromatic blocks were visualized in only three chromosome pairs, and chromomycin $\mathrm{A}_{3}{ }^{+}$bands were coincident with Ag-NORs. Although no intercalary (TTAGGG) sequence was observed through FISH with a telomere probe, an asymmetric karyotype showing four large chromosome pairs with diploid chromosome number reduction suggests that tandem chromosome fusions probably occurred during the karyotypic differentiation of Imparfinis hollandi.
\end{abstract}

Key words: Siluriformes, chromosome banding, chromosomal rearrangements, (TTAGGG) $)_{n}$.

Received: August 21, 2006; Accepted: May 22, 2007.

Comprising 1,548 valid species grouped into 15 families, Siluriformes is the most diversified and widely distributed Ostariophysi fish order, and its members are commonly known as catfishes (Reis et al., 2003) and occur in all continents. The genus Imparfinis belongs to Heptapteridae, an endemic family of the Neotropics that includes 26 genera of small to medium-sized fishes with 186 valid species (Bockmann and Guazzelli, 2003). Imparfinis hollandi was previously identified as Pariolius hollandi (Julio et al., 1997) or Heptaterus hollandi (Eschmeyer, 1998), thus reflecting the systematic difficulties of this group. Recent studies in Heptapteridae have been performed in order to discover the family phylogeny and to provide major rearrangements in the classification of the group, as well as to recognize the correct name of some taxa, since the species-level taxonomy is poorly developed in their genera (Pinna, 1998; Bockmann and Guazzelli, 2003).

Among Siluriformes, the diploid number ranges from $2 n=22$ to 132 chromosomes, with a modal number of 58 chromosomes; this variation is due to chromosomal rearrangements associated with the speciation process (Oliveira et al., 1988). LeGrande (1981) suggested an ancestral

Send correspondence to Vladimir Pavan Margarido. Centro de Ciências Biológicas e da Saúde, Universidade Estadual do Oeste do Paraná, Rua Universitária 2069, 85819-110 Cascavel, PR, Brazil. E-mail: vpmargarido@unioeste.br. karyotype with $2 \mathrm{n}=56 \pm 2$ and a relatively high fundamental number (up to 80). Moreover, Oliveira and Gosztonyi (2000), through the study of Diplomystes mesembrinus, a representative of the most primitive family of Siluriformes (Diplomystidae), revealed a diploid number of 56 chromosomes, which is considered as the most basal in this fish order. It is important to emphasize that the relative chromosomal condensation hinders the determination of the chromosome type as well as the organization of the fish karyotype, implying in some comparison difficulties among Siluriformes karyotypes (LeGrande, 1981). Among Heptapteridae fish, the diploid number ranges from $2 n=46$ chromosomes in Pimelodella avanhandavae (Vissoto et al., 1999) and Pimelodella aff. meeki (Dias and Giuliano-Caetano, 2002), to 58 chromosomes in Cetopsorhamdia iheringi (Vissoto et al., 1999), Pimelodella kronei (Almeida-Toledo et al., 1992), and Rhamdia species (R. hillari, Fenocchio and Bertollo, 1990; R. branneri and $R$. voulezi, Abucarma and Martins-Santos, 2001; R. quelen, Stivari and Martins-Santos, 2004). The Imparfinis species studied until now show a diploid number of 56 (Imparfinis $\mathrm{cf}$. piperatus, Vissoto et al., 2001) to 58 chromosomes (Imparfinis mirini, Vissoto et al., 1997; Imparfinis piperatus, Vissoto et al., 2001; Imparfinis aff. shubarti, Stolf et al., 2004).

Due to the rare occurrence of Imparfinis hollandi, only three individuals (2 males and 1 female) were collected from the Salto Osório reservoir of the Iguaçu River, 
in Quedas do Iguaçu (Paraná State, Brazil). Mitotic chromosomes were obtained from kidney cells. Ag-NOR (Nucleolar Organizer Regions) sites were detected using silver nitrate staining. Chromomycin $\mathrm{A}_{3}$ staining, using distamycin $\mathrm{A}$ as a counterstaining, was performed to investigate $\mathrm{GC}$-rich isochores. C-banding was produced with barium hydroxide. The classification of chromosomes in metacentric (m), submetacentric (sm), and subtelocentric (st) followed the arm ratio criterion, and the chromosomes were organized into types and in a decreasing order of size in the karyotype. All these methods were carried out according to procedures found in Margarido and Galetti (2000). A telomere repeat probe was generated by PCR according to IJdo et al. (1991) using primers (TTAGGG) $)_{5}$ and (CCCTAA) $)_{5}$. The probe was marked with 14-dATP biotin by nick translation following the manufacturer's instructions (Bionick Labelling System - Invitrogen). Chromosomes were denatured in $0.05 \mathrm{~N} \mathrm{NaOH} / 2 \times \mathrm{xSC}$ for $3 \mathrm{~min}$. After overnight hybridization at $37{ }^{\circ} \mathrm{C}$, the hybridization signal was detected using conjugated avidin-fluorescein (FITC) and biotinylated anti-avidin antibody. Chromosomes were counterstained with propidium iodide $(50 \mu \mathrm{g} / \mathrm{mL})$ and analyzed with an Olympus BX50 epifluorescence microscope. Chromosome images were captured with the use of the CoolSNAP-Pro software (Media Cybernetic).

The diploid chromosome number determined for Imparfinis hollandi $(2 \mathrm{n}=42 ; 22 \mathrm{~m}+10 \mathrm{sm}+10 \mathrm{st})$ (Figure 1a) is different from the diploid number of all the other Imparfinis species studied until now (predominantly $2 \mathrm{n}=58$; Vissoto et al., 1997; Vissoto et al., 2001; Stolf et al., 2004), and is the lowest diploid number in the Heptapteridae family. Until the present study, the lowest diploid chromosome number described for a heptapterid fish was $2 \mathrm{n}=46$ chromosomes in the genus Pimelodella (Vissoto et al., 1999; Dias and Giuliano-Caetano, 2002). Even though Pimelodella shows $2 \mathrm{n}=46$ chromosomes, the karyotype of this species is symmetric. This stands in contrast with Imparfinis hollandi which shows an asymmetric karyotype with four outstandingly large chromosomes pairs (pairs $1 \mathrm{~m}, 2 \mathrm{~m}, 12 \mathrm{sm}$, and $17 \mathrm{st}$ ) that correspond to almost twice the size of the other chromosomes in the complement, a characteristic not shared by any studied heptapterid. This diploid chromosome number reduction suggests that tandem chromosome fusions may have occurred during the karyotypic differentiation of this species. Despite the fact that C-banding showed a reduced amount of heterochromatin (Figure 1b), like in other Heptapteridae (Abucarma and Martins-Santos, 2001; Swarça et al., 2003; Stolf et al., 2004), these results corroborate the idea of chromosome fusions. Although dark heterochromatic blocks were observed in only three chromosome pairs (numbers 8,12 , and 18), slightly differential longitudinal staining can be observed in the four larger chromosome pairs by both Giemsa staining and C-banding, in accordance with the suggestion
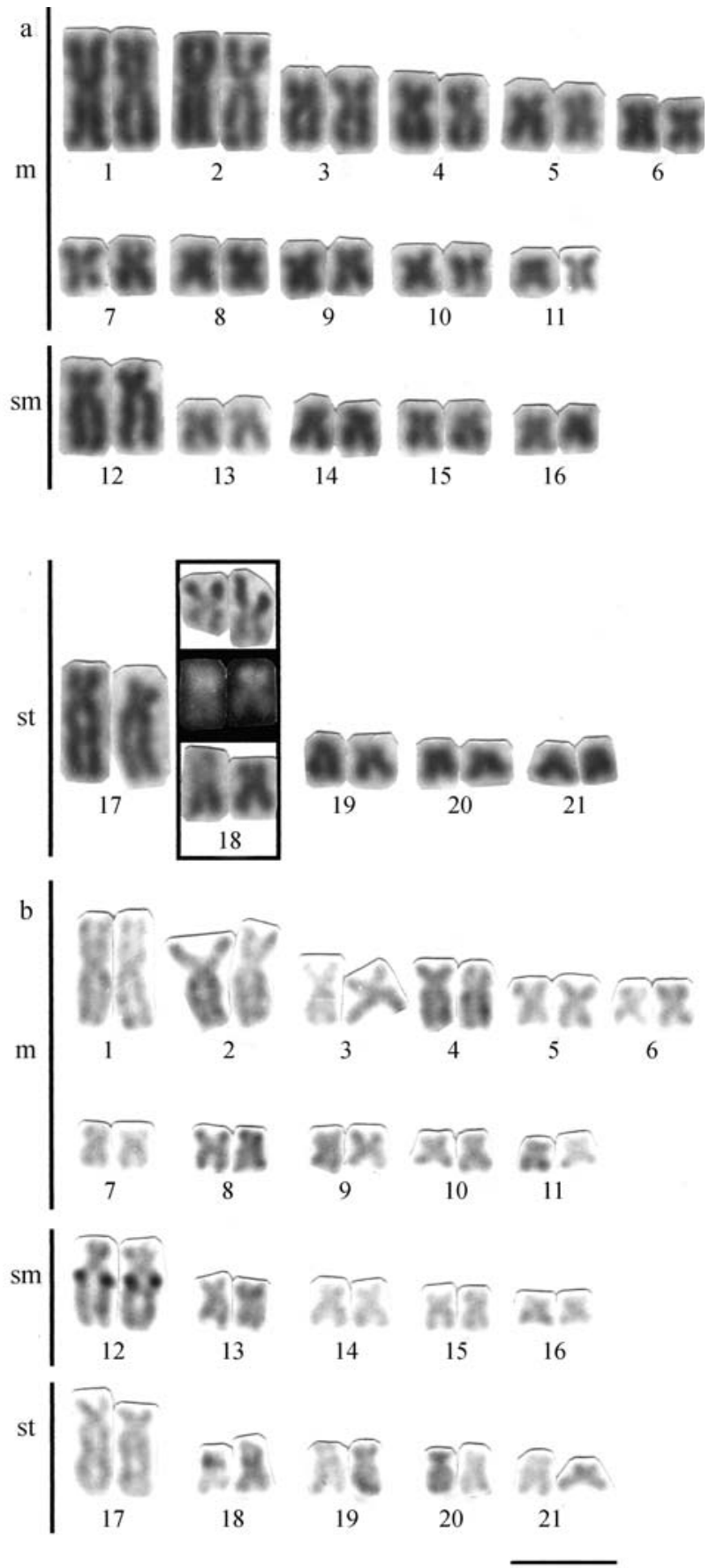

Figure 1 - Karyotypes of Imparfinis hollandi Giemsa-stained (a), and C-banded (b). The NOR bearing pair chromosomes (pair 18) are detailed in the box (a), stained by silver nitrate (above), Chromomycin $\mathrm{A}_{3}$ (center), and Giemsa (below). Bar $=5 \mu \mathrm{m}$.

of their origin though the fusion of ancestral minor chromosomes.

A prerequisite for fusion should either be elimination or inactivation of telomeres (Slijepcevic, 1998), since telomeres are specialized structures at chromosome ends required for maintaining chromosome stability and integrity (Zakian, 1997). The absence of intercalary 
(TTAGGG) $)_{\mathrm{n}}$ sites in the four larger chromosome pairs of Imparfinis hollandi indicates the elimination of telomeres during fusion of ancestral minor chromosomes (Figure 2). Another explanation is the high stringency used in the FISH technique since the hybridization solution consisted of $50 \%$ formamide. Abuín et al. (1996) reported the verification (presence/absence) of interstitial telomeric sequences by varying the formamide concentration (low/ high, respectively). On the contrary, Meyne et al. (1990) verified the occurrence of interstitial telomeric sites from a number of vertebrate species, suggesting fusion without telomere loss. In fish, chromosome fusion has been reported in processes involved in the differentiation of multiple sex chromosome systems mainly through centric fusion of acrocentric chromosomes, such as in Eigenmannia sp. (Almeida-Toledo et al., 2000a), Brachyhypopomus pinnicaudatus (Almeida-Toledo et al., 2000b), Erythrinus eyrthrinus (Bertollo et al., 2004), Gymnotus pantanal (cited as Gymnotus sp., Silva and Margarido, 2005), and Harttia carvalhoi (Centofante et al., 2006), although fusion between metacentric and submetacentric chromosomes had already been well documented in Hoplias malabaricus (Bertollo et al., 1997).

In conclusion, silver and $\mathrm{CMA}_{3}{ }^{+}$staining were neither good tools to detect rearrangements in karyotype structure nor good cytogenetic markers, since only pair 18 was evidenced by both techniques (Figure 1a). A single chromosome pair bearing either NORs or $\mathrm{CMA}_{3}{ }^{+}$bands is a common feature shared by several Heptapteridae (Swarça et al., 2003; Stolf et al., 2004). Furthermore, the data presented in this study confirm that karyotypic evolution in Heptapteridae is more divergent than conservative and that more studies, especially morphological and cytogenetic analyses, would be of great value in order to better understand the family systematics and evolution and the chromosomal mechanisms involved in the speciation process.

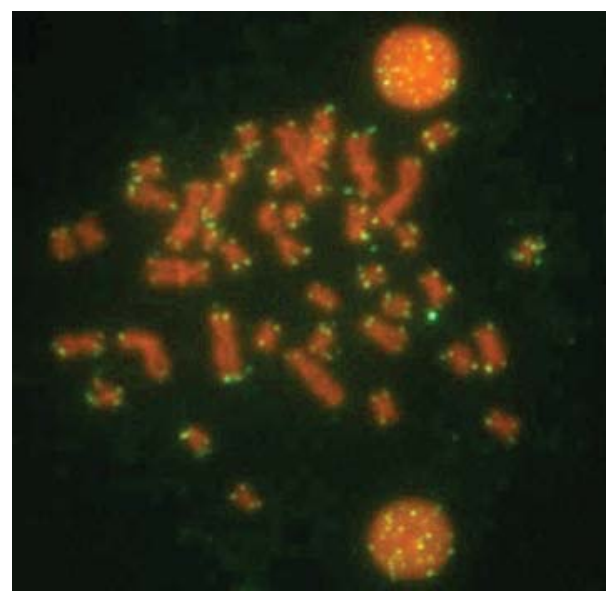

Figure 2 - Metaphase of Imparfinis hollandi after fluorescence in situ hybridization with telomere probe (TTAGGG) .

\section{Acknowledgments}

The authors are grateful to Marcos Paulo Roman for his help in the fish capture. This work was supported by Unioeste-Campus Cascavel.

\section{References}

Abucarma M and Martins-Santos IC (2001) Karyotype and B chromosome of Rhamdia species (Pisces, Pimelodidae) endemic in the River Iguaçu basin. Cytologia 66:299-306.

Abuín M, Martínez P and Sánchez L (1996) Localization of the repetitive telomeric sequence (TTAGGG) in four salmonid species. Genome 39:1035-1038.

Almeida-Toledo LF, Foresti F, Trajano E and Toledo-Filho AS (1992) Cytogenetic analysis of the blind catfish Pimelodella kronei and of its presumed ancestor Pimelodella transitoria. Caryologia 45:255-262.

Almeida-Toledo LF, Foresti F, Daniel MFZ and Toledo-Filho SA (2000a) Sex chromosome evolution in fish: The formation of the neo-Y chromosome in Eigenmannia (Gymnotiformes). Chromosoma 109:197-200.

Almeida-Toledo LF, Foresti F, Daniel MFZ, Lopes CE and Toledo-Filho SA (2000b) Sex chromosome evolution in fish. II. Second occurrence of an $\mathrm{X}_{1} \mathrm{X}_{2} \mathrm{Y}$ sex chromosome system in Gymnotiformes. Chrom Res 8:335-340.

Bertollo LAC, Fontes MS, Fenocchio AS and Cano J (1997) The $\mathrm{X}_{1} \mathrm{X}_{2} \mathrm{Y}$ sex chromosome system in the fish Hoplias malabaricus. I. G-, C- and chromosome replication banding. Chrom Res 5:493-499.

Bertollo LAC, Oliveira C, Molina WF, Margarido VP, Fontes MS, Pastori MC, Falcão JN and Fenocchio AS (2004) Chromosome evolution in the erythrinid fish, Erythrinus erythrinus (Teleostei, Characiformes). Heredity 93:228233.

Bockmann FA and Guazzelli GM (2003) Family Heptateridae. In: Reis RE, Kullander SO and Ferraris Jr CJ (eds) Check List of the Freshwaters of South and Central America. EDIPUCRS 1, Porto Alegre, pp 406-431.

Centofante L, Bertollo LAC and Moreira-Filho O (2006) Cytogenetic characterization and description of an $\mathrm{XX} / \mathrm{XY}_{1} \mathrm{Y}_{2}$ sex chromosome system in catfish Harttia carvalhoi (Siluriformes, Loricariidae). Cytogenet Genome Res 112:320-324.

Dias AL and Giuliano Caetano L (2002) Citogenética de alguns grupos de peixes do rio Tibagi. In: Medri ME, Bianchini E, Shibatta OA and Pimenta JA (eds) A Bacia do Rio Tibagi. EDUEL, Londrina, pp 473-529.

Eschmeyer WN (1998) Catalog of Fishes. California Academy of Sciences, San Francisco, 2905 pp.

Fenocchio AS and Bertollo LAC (1990) Supranumerary chromosomes in a Rhamdia hilarii population (Pisces, Pimelodidae). Genetica 81:193-198.

Ijdo JW, Wells RA, Baldini A and Reeders ST (1991) Improved telomere detection using a telomere repeat probe $(\text { TTAGGG) })_{n}$ generated by PCR. Nucleic Acid Res 19:4780.

Júlio Jr HF, Bonecker CC and Agostinho AA (1997) Reservatório de Segredo e sua inserção na bacia do rio Iguaçu. In: Agostinho AA and Gomes LC (eds) Reservatório de Segredo: Bases Ecológicas para o Manejo. EDUEM, Maringá, pp 1-15. 
LeGrande WH (1981) Chromosomal evolution in North American catfishes (Siluriformes, Ictaluridae) with particular emphasis on the madtoms, Noturus. Copeia 1:33-52.

Margarido VP and Galetti Jr PM (2000) Amplification of a GCrich heterochromatin in the freshwater fish Leporinus desmotes (Characiformes, Anostomidae). Genet Mol Biol 23:569-573.

Meyne J, Baker RJ, Hobart HH, Hsu TC, Ryder OA, Ward OG, Wiley JE, Wurster-Hill DH, Yates TL and Moyzis RK (1990) Distribution of nontelomeric sites of (TTAGGG) telomeric sequences in vertebrate chromosomes. Chromosoma 99:3-10.

Oliveira C and Gosztony AE (2000) A cytogenetic study of Diplomystes mesembrinus (Teleostei, Siluriformes, Diplomystidae) with a discussion of chromosome evolution in siluriforms. Caryologia 53:31-37.

Oliveira C, Almeida-Toledo LF, Foresti F, Britski HA and Toledo-Filho SA (1988) Chromosome formulae of neotropical freshwater fishes. Braz J Genet 11:577-624.

Pinna MCC (1998) Phylogenetic relationships of Neotropical Siluriformes (Teleostei, Ostariophysi): Historical overview and synthesis of hypotheses. In: Malabarba LR, Reis RE, Vari RP, Lucena ZMS and Lucena CAS (eds) Phylogeny and Classification of Neotropical Fishes. EDIPUCRS, Porto Alegre, pp 279-330.

Reis RE, Kullander SO and Ferraris Jr CJ (2003) Check List of the Freshwaters of South and Central America. EDIPUCRS 1, Porto Alegre, 729 pp.
Silva EB and Margarido VP (2005) An $X_{1} X_{1} X_{2} X_{2} / X_{1} X_{2} Y$ multiple sex chromosome system in a new species of the genus Gymnotus (Pisces, Gymnotiformes). Environ Biol Fishes 73:293-297.

Slijepcevic P (1998) Telomeres and mechanisms of Robertsonian fusion. Chromosoma 107:136-140.

Stivari MK and Martins-Santos IC (2004) Karyotype diversity in two populations of Rhamdia quelen (Pisces, Heptateridae). Cytologia 69:25-43.

Stolf R, Swarça AC, Giuliano-Caetano L and Dias AL (2004) Analysis of karyotype and nucleolus organizer regions of Imparfinis aff. shubarti (Siluriformes, Pimelodidae) of the Tibagi river basin, Paraná, Brazil. Caryologia 57:348-352.

Swarça AC, Vidotto AP and Dias AL (2003) Cytogenetic characterization of Pimelodella aff. avanhandavae (Siluriformes, Pimelodidade) from Tibagi river (Paraná State, Brazil). Caryologia 56:421-425.

Vissoto PC, Foresti F and Oliveira C (1997) A ZZ/ZW sex chromosome system in Imparfinis mirini (Pisces, Siluriformes). Cytologia 62:61-66.

Vissoto PC, Foresti F and Oliveira C (1999) Karyotype description of five species of Pimelodidae (Teleostei, Siluriformes). Chrom Sci 3:1-7.

Vissoto PC, Foresti F and Oliveira C (2001) Karyotypic characterization of two species of the genus Imparfinis (Teleostei, Siluriformes, Heptateridae). Chrom Sci 5:97-103.

Zakian VA (1997). Life and cancer without telomerase. Cell 91:1-3.

Associate Editor: Lurdes Foresti de Almeida-Toledo

License information: This is an open-access article distributed under the terms of the Creative Commons Attribution License, which permits unrestricted use, distribution, and reproduction in any medium, provided the original work is properly cited. 